\title{
Responding to the critics: Implementation of TBLT in Japan
}

\author{
Justin Harris \\ Faculty of Economics, Kindai University, Osaka, Japan
}

\begin{abstract}
This paper outlines a qualitative study of 10 in-service teachers in Japan who use a task-based language teaching (TBLT) approach in their language classrooms. The study investigates the reasons why these teachers began using TBLT, their beliefs about the advantages and disadvantages of implementing TBLT, and whether or not they agree with common criticisms levelled at TBLT for use in foreign language classrooms in Japan and Asia in general. Critics argue that TBLT is not suitable for many language learning situations, explaining that students are used to more 'traditional' teacher-centered language classes and that they prefer more 'passive' approaches. Such criticisms also hold that TBLT is not able to adequately prepare students for the high-stakes tests that are used for secondary school and university entrance purposes. The results from interviews with these 10 teachers suggest that they reject many of these criticisms, and are in fact successfully using TBLT to develop both language ability and motivation in their students. At the same time, the teachers noted that there may be a need to use a 'weaker' form of TBLT with beginner students, or with those used to more passive styles of learning. They also highlighted the importance of heavily scaffolding tasks in such cases. Finally, a number of the teachers discussed the need for the development of more TBLT related materials, both for students and teachers.
\end{abstract}

Keywords: task-based language teaching; teacher beliefs; teaching methodology

\begin{tabular}{|c|c|c|}
\hline $\begin{array}{l}\text { First Received: } \\
\text { 1 February } 2018\end{array}$ & $\begin{array}{c}\text { Revised: } \\
\text { 11 April } 2018\end{array}$ & $\begin{array}{c}\text { Accepted: } \\
13 \text { April } 2018\end{array}$ \\
\hline $\begin{array}{c}\text { Final Proof Received } \\
29 \text { May } 2018\end{array}$ & & $\begin{array}{l}\text { Published: } \\
31 \text { May } 2018\end{array}$ \\
\hline \multicolumn{3}{|c|}{$\begin{array}{l}\text { How to cite (in APA style): } \\
\text { Harris, J. (2018). Responding to the critics: Implementation of TBLT in Japan. Indonesian } \\
\text { Journal of Applied Linguistics, } 8(1) \text {, pp. } 139-148 \text {. doi: } 10.17509 / \text { ijal.v8i1.11473 }\end{array}$} \\
\hline
\end{tabular}

\section{INTRODUCTION}

This paper outlines a qualitative study of ten in-service teachers who use a task-based language teaching (TBLT) approach in foreign language classrooms in Japan. The study investigates the reasons why these teachers began using TBLT, their beliefs about the advantages and disadvantages of the approach, and whether or not they agree with common criticisms against the use of TBLT in foreign language classrooms in Japan. Critics question the suitability of TBLT for language teaching in Japan, arguing that many, if not most students are used to 'traditional' teacher-centered language classes, prefer a more 'passive' learning style, and that TBLT is not suitable in preparing for the highstakes tests for which many students in Japan (and many parts of Asia) learn English.
It is not difficult to find articles in newspapers and blogs decrying the state of English as a foreign language education in Japan (Chen, 2014; Clark, 2009; Miller, 2014; Wakabayashi, 2015). Journalists, teachers, university professors, parents, all seem willing to critique the present language teaching system. Common to these arguments is the fact that many (if not most) English classes focus on passing tests, that there is a lack of adequate teacher training for language teachers, and that 'traditional' grammar-translation teaching methods allow little room for developing communicative ability. In response to a century or more of the grammar-translation method in formal schooling, the communicative language teaching (CLT) boom in the 1980's did have an impact in Japan. Often, the result has been the implementation of a PPP approach where,

\footnotetext{
* Corresponding author:

Email: jharris42@kindai.ac.jp
} 
as the abbreviation denotes, the target language is first 'presented', then students 'practice', and subsequently 'produce' it. PPP is 'communicative' in the sense that students are using the language, and it provides teachers the safety of knowing what language will be used in class (it's pre-defined), and the writers of textbooks the relatively simple job of deciding which language to 'present'. However, the main argument against PPP is that it doesn't allow students to communicate in meaningful, authentic ways, and that subsequently (and more importantly), that it is not effective in developing the very skill it is intended to bring about, communicative ability in the target language (Skehan, 1998; Willis \& Willis, 2009).

The gradual (and for the most part 'bottom-up') introduction of TBLT in English classes in Japan is an attempt to address this, in the sense that within a TBLT approach, language is treated as a meaningful communicative tool, rather than as an object of study. Due to the potential of TBLT for developing language skills and motivation in students (Ellis, 2003; Willis \& Willis, 2007) the popularity of the method has continued to grow in Japan (Lowe, 2012), which has led many teaching practitioners to implement it in classrooms across the country. The result is an increase in research on the topic, with TBLT appearing frequently in local journals, conference presentations, the establishment in 2011 of a local academic group dedicated to the study of TBLT, and the TBLT in Asia conference series, which has been held biennially since 2012. TBLT is now used across multiple teaching contexts in Japan, from young learners to tertiary students. At the same time, TBLT has received criticism from some as being unsuitable for language learning in the Japanese education system, citing for example, learning styles and culture specific reasons for avoiding it.

This paper outlines a qualitative study investigating the use of TBLT in Japan by ten teachers who are presently using the method, or who have used it in the past. It seeks to find out these teachers' beliefs about the advantages and drawbacks of using TBLT in Japan. It investigates some of the real issues they have faced in the process, and their beliefs about the criticisms often levelled at TBLT in Japan. The growing number of studies on teacher beliefs (Borg, 2006) attests to its value in research in education, but there are still very few studies of teacher beliefs about the use of TBLT in language teaching (Viet, 2014). The studies that do exist tend to focus on how public school teachers have reacted to top-down implementation of TBLT, in either accepting or rejecting it, and reasons for rejection (Cheng \& Moses, 2011; Hu, 2013; Jeon, 2006; Li, 1998). This study attempts to add to this area of knowledge with data from interviews with ten teachers from various teaching backgrounds working in Japan in a range of teaching contexts regarding the ways that they are implementing TBLT in their classrooms, and the challenges they have met along the way.
The study investigates three simple questions. First, what motivated teachers to implement TBLT in their classes? Second, what do teachers see to be the advantages of using TBLT in their classes? Third, according to the teachers themselves, what are the real issues related to using TBLT in Japan? Finally, with regard to the last question, the study aims to discover whether or not teachers agree with arguments sometimes proposed as 'obstacles' to implementing TBLT in Japan (and Asia in general). Discovering what practicing teachers consider to be the actual issues related to using TBLT in Japan is important as it can help other teachers who are struggling with the same issues to find solutions. It might also help those teachers who have previously been reluctant to use TBLT methods in their classes. It is hoped that the results can be of use to teachers working in similar EFL environments in Japan and Asia.

\section{Task-based language teaching}

Various definitions of TBLT appear in the literature, but most proponents agree that TBLT is a teaching approach in which the 'task' becomes the focal point of a language class. It is also generally agreed that this task should; a) have a focus on meaning; b) be related to real-world activities; and c) that assessment of the successful completion of the task should be made based on the outcome of the task itself (Skehan, 1998). Generally considered to be a refinement of the CLT approach, TBLT however places importance on form, as well as communicative ability, often through a post-task 'focus on form'.

\section{Benefits}

Over the last few decades, a growing body of research has pointed to a number of benefits for learners stemming from the use of TBLT in the classroom. TBLT has been shown to develop speaking skills and general language skills (Kozawa, 2011; Mackey, 1999), vocabulary acquisition (Newton, 2001), language automaticity (De Ridder, Vangehuchten \& Gomez, 2007), pragmatic ability (Takimoto, 2007), student autonomy (Willis \& Willis, 2011) and motivation and student engagement (Ellis, 2003; Willis \& Willis, 2011). This last point is extremely important in Japan, where it is not rare for students to lack motivation or desire to use the L2. TBLT allows learners to use language to communicate freely, and without fear of penalty for making grammatical or pronunciation mistakes (Willis \& Willis 2007). It also allows for students' creativity (Nunan, 2004) and avoids excessive prescriptivism, as learners can come to realise that there is often more than one right answer or way of doing things with language.

\section{Issues}

There is however, doubt about the effectiveness of TBLT for language learning. Critics argue that a TBLT approach lacks adequate focus on form (Sheen, 2003; Swan, 2005), that it results in deficiencies with uptake of grammar and vocabulary (Bruton, 2005), that a heavy 
emphasis on communication will result in learners not gaining a complete understanding of correct forms (Seedhouse, 1999), that beginner language users need a grounding in grammar first (Swan, 2005), or at the very least that there is not yet enough solid empirical evidence to back up the efficacy of TBLT (Swan, 2005).

Context-specific arguments compound the issue, and it is these points that this paper primarily deals with. TBLT is often described antithetically to 'traditional' instruction methods (Luo \& Xing, 2015; Shintani, 2011; Willis \& Willis, 2009) and it is probably this different approach to teaching that invites criticism. A common premise holds that many parts of Asia have 'Confucian heritage' style teaching cultures (Hu, 2005; Sato, 2009; Zheng, 2015) which are held to be synthetic (Carless, 2007), teacher-centred (Zhang, 2015), and 'grammarbased' (Long, 2015), making a 'student-centred' TBLT difficult. Closely related to the 'teacher-centred' argument, class-size is also brought up as an issue in Asia (for example Zheng \& Borg 2014). Another commonly discussed concern is that TBLT conflicts with students' previous educational experiences and expectations, which may have been more passive in nature (Burrows, 2008; Sato, 2009). This can be traced back to similar criticisms of CLT. Over two decades ago, Anderson explained that (in her case Chinese) "students may be perplexed by the communicative approach since they are not accustomed to it" (Anderson, 1993, p. 473). Carless (2004) argues that when TBLT is introduced to students coming from a more passive educational background, discipline and noise issues may surface. Also, students may feel that they are not learning anything in communicative classes if they are not focused enough on grammar and vocabulary exercises ( $\mathrm{Li}, 1998)$. It has also been argued that students' future foreign language needs may not necessarily be communicative anyway (Carless, 2007). The focus on passing high-stakes exams is also given as another reason for avoiding TBLT (Li, 1998; Littlewood, 2007) because, it is argued, TBLT does not allow focus on discrete test items. Yet another recurring argument in the literature is that students in Japan have a fear of making mistakes (McVeigh, 2001; Nakane \& Ellwood, 2009; Wicking, 2009), and because TBLT places central importance on using the L2, it is therefore inappropriate.

\section{Different interpretations of TBLT}

With both general and context-specific arguments, one thing holds true. They tend to view TBLT as a fixed method with no room for adaption. Ellis (2009), in his outline of 12 "misunderstandings" of TBLT, explains that many of these criticisms can be answered simply by a better understanding of what TBLT can be, and part of this is the ability to adapt TBLT to each teaching situation. One common misunderstanding is that because TBLT is inherently student-centred, it is difficult to implement in traditionally 'teacher-centred' educational contexts. He argues however that TBLT can actually be easily carried out in plenary style. Shintani
(2016) explains that the issue of large class sizes is largely irrelevant if input tasks are used. Ellis' oft-cited quote "there is no single way of doing TBLT" (Ellis, 2009, p. 224) is pertinent here. In his 2017 position paper, Ellis expands on this by stating that "alternative versions of TBLT are possible and indeed necessary to accommodate different instructional contexts" (Ellis, 2017 , p. 508) which brings us to context of this study.

\section{The context}

The implementation of TBLT discussed here is multicontextual, occurring in a number of learning institutions, with teachers from a variety of teaching backgrounds, and with learners of many different ages in Japan. English as a foreign language is generally taught as a compulsory subject for six years through junior high school and high school. In addition, most universities, both public and private, require students to study English for at least another year regardless of their major. In addition, the study of English is gradually being introduced at elementary schools in increasingly formal ways. Beginning in 2002 with kokusaika (internationalization) studies, gaikokugo katsudo (foreign language activities) was introduced as a 'nonacademic' class, and then in 2011 as a compulsory subject for all $5^{\text {th }}$ and $6^{\text {th }}$ grade pupils (although it is still not a formally assessed part of the curriculum). Presently, plans are in place for English to be introduced as a formal subject from the third grade of elementary school from the year 2020, although schools will be able to start this from 2018 ("Third-graders can get", 2017). Thus, if they plan to attend university, students beginning the third grade in 2020 can expect to experience at least 11 years of English classes. With so much time and money being allocated to the teaching of English in Japan, appropriate methodology is indeed a big issue.

In some Asian countries the search for an appropriate methodology that helps to develop communicative competence has led to a situation where TBLT has been introduced in a top-down fashion. (Lai, 2015). At the same time, in many such countries, teachers who are faced with using a TBLT approach have chosen to adapt it (Carless, 2004; Viet, Cahn, \& Barnard, 2015) or in some cases, have even gone so far as to avoid it completely (Hu, 2013; Jeon, 2006). The reasons for this often stem from teachers' lack of confidence or knowledge about TBLT (Jeon, 2006), or perceived socio-cultural and contextual factors (Burrows, 2008; Sato, 2010) involving learners, teachers, and institutions (Lai, 2015). Other reasons can include lack of appropriate textbooks and support materials (Luo \& Xing, 2016).

While Japan has not experienced the top-down push for TBLT at government level that some other Asian countries have seen, support of general communicative approaches in Ministry of Education guidelines (MEXT, 2014), has resulted in TBLT being implemented across many different language teaching contexts. Such change brings with it criticism (as 
outlined above). Yet there has been very little work done on the beliefs of teachers who are actually carrying out TBLT in foreign language classrooms in Japan. Harris (2016) outlined a survey study of 78 teachers based in Japan who are using or previously used a TBLT approach. Results showed that many of these teachers believed common criticisms of TBLT to be misplaced, and that with certain adaptions, TBLT can be successfully implemented in Japan. This paper aims to provide a more detailed picture of such teacher beliefs through a qualitative study. In regard to this, how do the ten teachers interviewed for this paper use TBLT? It is to their responses that we now turn.

\section{METHOD}

\section{Participants}

The ten teachers interviewed for this paper were from a variety of teaching backgrounds (outlined in table 1), based in junior high schools, senior high schools, and universities, while two were teachers of adult-learners. Thus, the only major learning situation not covered was that of very young learners in kindergarten or elementary schools, although one teacher, Naoko, had previously taught very young learners. The length of experience of these teachers ranged from 4 years to 31 years, and the sample included both Japanese and English native speakers. The interviewees were chosen from a larger group of teachers who had completed an online survey on a wider set of questions concerning TBLT in Japan. With the exception of one teacher, the interviewees were using TBLT in their classes at the time of interview. The one teacher who was not (Yumiko) had previously used TBLT in her classes for seven years, but after taking up a new position that involved a lot of non-teaching work, she found the timeconsuming nature of preparing for TBLT lessons too much, and stopped. The names of all teachers have been changed for the purpose of confidentiality.

Table 1. Interviewee data

\begin{tabular}{lllc}
\hline Name & $\begin{array}{c}\text { Main teaching } \\
\text { context }\end{array}$ & $\begin{array}{c}\text { Native } \\
\text { language(s) }\end{array}$ & $\begin{array}{c}\text { No. of years } \\
\text { teaching }\end{array}$ \\
\hline Calvin & Senior high & English & 4 \\
Chad & Adult learners & English & 15 \\
Fumiya & Tertiary & Japanese & 6 \\
Hannah & Business classes & English & 22 \\
Jane & Tertiary & English & 23 \\
Naoko & Tertiary & Japanese & 8 \\
Nathan & Junior & English & 5 \\
& high/Tertiary & & \\
Susan & JHS / Tertiary & English & 30 \\
Winston & Tertiary & English & 26 \\
Yumiko & Tertiary & Japanese & 31 \\
\hline
\end{tabular}

\section{Procedure}

As a follow-up to a larger survey and interview study, these 10 teachers were asked questions about their reasons for implementing a TBLT approach in their classes, the successes and difficulties they have had, and the extent to which they agree or disagree with arguments against the use of TBLT in Japan. Interviews were carried out either by Skype or by email, based on respondents' wishes. Regardless of interview method, respondents were asked the same set of questions. However, those replying by email were sometimes contacted with follow-up questions for clarification of their answers. The study investigates three research questions;

1. For what reasons do teachers start using TBLT in classes in Japan?

2. What are the main advantages to using TBLT in classes in Japan?

3. Are there any drawbacks to using TBLT in classes in Japan?

Related to the last question, teachers were given a set of statements and asked if they agreed or disagreed with each one. They were asked to expand on their answers where they felt necessary, and most teachers chose to do so. The interview data were then added to an Excel file and coded in accordance with thematic analysis guidelines (Gillham, 2005). From this analysis, certain themes emerged and these are discussed below.

\section{FINDINGS AND DISCUSSION}

\section{Motivation for introducing a TBLT approach in classes}

The majority of teachers had come to use TBLT in their classrooms after being introduced to it in formal teacher training (DELTA certificate) or while studying towards higher degrees in TESOL or education. Some of the teachers mentioned that after being introduced to the method in these courses, they had tried it out in their classes and had seen a noticeable difference in how their students responded. This highlights the importance of including modules on TBLT in teacher training courses. Two of the respondents discovered the approach after reading about it. William explained that his students found information gap "communicative activities" (his use of quotes) in the textbook he was using to be uninteresting, but his discovery of a new ELT textbook featuring activities of a task-based nature turned this around. Subsequent reading of teacher training resources led him to try TBLT in his classes. Nathan's experience was very similar:

Nathan: ...something about using tasks resonated as I thought they were very practical, unlike the very guided and structured activities I had been doing with students. So after learning exactly what it was, I took some textbook activities and adjusted them to better fit a task. The students did much better and looked to be having fun.

Calvin found the method through reading Dave and Jane Willis' Doing Task-based Teaching (Willis \& Willis, 2007) and only one of the respondents had come to use it in a top-down manner. Her boss had first 
introduced her to the method, explaining it was the best way to engage students and hold their attention.

\section{Main advantages of using TBLT in classes}

The most common thread that appeared in interviewees' responses to this statement concerned an improvement in student engagement that comes with using TBLT. Half of the interviewees' alluded to the 'fun' or 'engaging' aspect of TBLT, many explaining that this is a direct result of the student-centred nature of the approach.

Fumiya: ...most of my students are more likely to engage in learning and discussing what they need to learn compared with when I keep lecturing on my own without interacting with students...

Naoko: ...many Japanese students don't want to study English and it's very hard to keep their attention. English classes can be very boring sometimes, especially when you teach subjects like grammar, so I thought TBLT worked...to keep students' attention...it's not boring, it has elements of game.

Susan: ...students are motivated to do the homework, because it is interesting (and) the lessons are more interesting and enjoyable for me.

Another point brought up by half of the teachers is that with TBLT, students are able to use their creativity, and are freer to talk about things that they want to

Nathan: ...learners have more choices during a task, so they can put more of their own personality into the means of completing each task.

Jane: It gives students the freedom to use the knowledge of English they have in a creative way.

Calvin: I've always found that the students can be a little more free in their language use. Sometimes what I expect for them to be working on in a task, they'll also create their own little subsection of the task that I wasn't really expecting but they sort of freely created it and sort of added it in.

Yumiko: My students were mostly diligent and good at memorizing what they were given to remember. And they were waiting for right answers without thinking by themselves. But in TBLT classes they tried to think by themselves.

Four of the teachers mentioned the way that TBLT develops autonomy in students. Nathan for example explained that after trying it in his classes for the first time, he noticed an increase in students consulting dictionaries, and more direct questions from the students to him and other teachers concerning language matters. Other teachers mentioned the authenticity of TBLT class content. Hannah explained that she first used TBLT in a classroom as a kind of "experiment". She found that the method encouraged "natural language use" in her students and this led her to continue using it. Finally, four of the teachers alluded to the potential of
TBLT in building student confidence and in alleviating fear of mistakes:

Hannah: Since there are no set parameters for what language is to be used, the students are much less worried about making mistakes and interact more naturally, with less self-monitoring.

Chad: TBLT encourages the learner to emerge as a language user, not just as a language learner.

\section{Drawbacks to using TBLT in classes}

To an extent, answers to this question varied, but a number of common points were raised by teachers. By far the most common regards the issue of learning styles that many students have become accustomed to in previous educational situations that sometimes conflict with a TBLT approach. Many teachers mentioned that students have come to classes with an educational background featuring a more 'passive' style of learning, and that suddenly introducing TBLT to these students can be rather confronting for them.

Hannah: TBLT doesn't suit the learning style of some students, particularly those who prefer a more teachercentered and grammar-focused classroom.

Fumiya: I sometimes feel hopeless when...students are completely passive and do not even engage in discussing what they are supposed to.

Chad: Japanese learners have traditionally studied in classrooms that use the grammar-translation method. As a result some students are more accustomed to focusing on the correct use of a target feature, rather than using language as a tool to communicate.

Calvin, a teacher from a private senior high school with a global studies focus, noted that this unfamiliarity with the more student-centred approach led some students to take advantage of it, something that teachers may need to be aware of and ready to deal with.

Calvin: I think that at times, task based learning, at least in my experience in Japan, at times to the students, may feel a little bit unstructured. It's not sort of what they're used to, and so they sort of feel that they're free, and maybe they take that freedom a little bit too far, and maybe do an entire task in Japanese, which isn't what I'm aiming for.

At the same time, a number of teachers didn't see these problems as being insurmountable, explaining that by gradually introducing tasks, and in particular by providing scaffolding support in the beginning, most students become used to, and appreciate TBLT approaches. Another issue brought up by teachers was assessment, something that is presently considered to be one of the major issues within TBLT (Long, 2016).

Jane: Students seem to want to be evaluated by tests because they like a quantitative system. They seem to think that 
they can't determine whether they have improved or not without looking at some numbers.

The other drawback (mentioned by three teachers) concerned availability of materials. A lack of readily available materials for use in TBLT classes (especially those matched to the level and expectations of their students) means that teachers need to spend a lot of time creating suitable materials, and this can cause difficulties for teachers. As well as materials for students, Fumiya mentioned the lack of practical materials for teachers, such as "concrete lesson plans" featuring examples of how to carry out tasks. This may be a result of the way that TBLT research has hitherto remained the domain of theorists conducting experiments "under laboratory conditions or in tightlycontrolled settings" (Van den Branden, 2006, p. 1). Greater focus on the practical implementation of TBLT would go some way to alleviate this issue.

\section{Common criticisms regarding the use of TBLT in Japan and Asia}

As an extension to the question of drawbacks to using TBLT in language classrooms in Japan, the interviewees were asked their opinions on issues related to context that have appeared in the literature. The teachers were asked if they found these criticisms on the use of TBLT in Japan and similar EFL contexts to be true, and if so, how they have dealt with them. Each statement is included below, along with representative comments from teachers.

\section{a) TBLT conflicts with a teacher-centered teaching tradition in Japan.}

Half of the interviewees agreed with this statement. At the same time, they provided examples of how they have dealt with the issue, or have made adaptions to get around it.

Hannah: Some students who are used to that style of teaching dislike the method and will complain. They expect explicit grammar focus, swift teacher-centered correction, and they often dislike being asked to do inductive reasoning, as they are used to teachers simply giving them the rules. To get around this, I specifically guide my students to become more autonomous. That is, I give them grammar-centered tasks at first, then as time goes by I take away the scaffolding as they become more independent. By the end of the course, they have no problems doing tasks on their own without any language parameters being set. And yes, I do get complaints once in a while; but the majority of the students enjoy the experience.

The idea of providing scaffolded support for students new to TBLT is something that has been proposed by TBLT researchers and practitioners in the past (Harris, 2016; Wicking, 2009; Widodo, 2015). Hannah provides an example of how, by slowly reducing that scaffolding, students can gradually become comfortable with less 'teacher focus' in class. Fumiya also had a salient point that TBLT can be used in teacher-centred classes, as Ellis (2009) has previously suggested. Finally, Calvin, a teacher of high school students, explained one further drawback related to teachers taking a less 'central' role in the classroom:

Calvin: Students have an expectation of the teacher being at the center....and I think that's where a lot of this ' $a$, we're completely free, we can do whatever we want' approach comes from.

He went on to explain however, that in his experience, such students were in the minority, and most of his students had generally taken to a TBLT approach. This wasn't the case however for all. Naomi had surveyed her students and many had expressed negativity towards communicative, student-centred classes. Naomi also offered a solution to this though, albeit one that is out of the hands of the individual teacher. She suggested that TBLT should be introduced to learners in schools throughout the country from their very first days of formal education.

\section{b) Classes in Japan are often large, so TBLT is unsuitable.}

This was the statement to which teachers were most unified in their disagreement. All but one of the ten teachers disagreed, many explaining that this was from personal experience teaching large classes with a TBLT approach. Shirley believed that rather than posing a problem, compared to more passive approaches, tasks help to keep students in large classes engaged. Even the one teacher who agreed with the statement explained that TBLT could still be implemented with larger classes, but that special measures (in this case recording tasks to smartphones to ensure L2 usage) would need to be taken. Many of the teachers who disagreed with the statement still brought up the need for good classroom management.

Fuyu: Even in classes with 45 students, I used TBLT and it worked well...although teachers will be busy walking around and giving them proper feedback.

Hannah: TBLT is a group-oriented methodology, and larger classes just mean more groups. The challenge then is the difficulty of monitoring a large number of groups, but an organized teacher can overcome that.

\section{c) Students in Japan are used to more traditional methods of teaching, so TBLT is unsuitable.}

Many teachers had already discussed this point in their answer to the third question about drawbacks (above), so will be briefly dealt with here. This statement proved to be one of the more contentious among the teachers in this study. Four teachers disagreed. Other teachers explained that while there may be such expectations from students, these can be overcome by introducing tasks slowly into classes (i.e. starting with a 'weak' form of TBLT and gradually 'strengthening' it). Fumiya mentioned that increasingly, senior high school and even junior high school students are experiencing TBLT or 'active learning' in their classes, so that many 
students in Japan are not necessarily unfamiliar with student-centred and 'active' approaches.

\section{d) Japanese students have a fear of making mistakes so TBLT is unsuitable.}

To this statement, six of the teachers clearly disagreed, some adding that TBLT instead alleviates fears that students might have.

Hannah: TBLT actually frees students from worrying about mistakes because they aren't being told to use a particular structure, which means they self-monitor much less. Japanese tend to be excessive self-monitors and focus more on grammar and structure than on meaning. But in doing tasks, they focus more on communicating in order to finish the task than on the errors they know they are making. They still worry about mistakes, but not to the extent that it hampers their fluency.

Others explained that while they thought 'fear of making mistakes' might actually be an issue for their students, this does not discount using TBLT in their classes.

Will: Depending on how the task is structured (c.f. Cooperative Learning), even quiet students can be made to contribute in L2 due to peer pressure and other factors. But in unstructured talk, such students can remain silent throughout the task.

Chad: Perhaps this is true initially. Over time students realize that language instruction doesn't always need to focus on forms.

\section{d) English classes in Japan are often aimed at passing tests, so TBLT is unsuitable.}

This might be the statement over which the interviewees were most divided, with an equal amount of agreement and disagreement. Some teachers pointed out that this is particularly an issue with pre-tertiary education, where the goal of English language lessons is very often to enter a good university via a paper test.

Jane: It depends on the level (universities have more freedom, so TBLT can be implemented there quite easily). However, as long as the (National) Centre Test focuses on specific (and mostly unnecessary) grammar points and phrases, TBLT is harder to implement in high schools. When the Centre Test disappears, maybe there will be room for TBLT at lower levels.

Will explained that because of this, "The biggest barrier is not the teachers or the students but the parents". Naomi also discussed the role of parents.

Naomi I personally think TBLT can work efficiently (to prepare for tests), but people, especially mothers, disagree... because mothers want their children to study grammar to pass the exams, or to have high scores on exams to get into good universities and high schools.

It is often argued that TBLT does not allow students to focus on discrete test items, and therefore that more 'traditional' approaches could be better. Hannah also brought this point up, explaining at the same time that, as a teacher of adults, this is not a major issue for her. Indeed, as Jane mentioned above, this is probably more of an issue for junior high school and high school teachers.

Hannah: Instructors are under time pressure to cover the particular structures required to pass the test. Since many of the tested structures are beyond the student's linguistic ability, it is not likely they will emerge during a task. I don't need to "get around" this point as I set the learning goals myself, and they are based on achieving communicative competence rather than grammatical knowledge

f) Because students in Japan generally have a lack of communicative ability, and because TBLT often focuses on using the L2 in the class, it is unsuitable (in that students need to study vocabulary and grammar first before using it to communicate).

Eight of the ten teachers replied with a unanimous 'no'. Some teachers felt that the idea of a 'lack of communicative ability' itself is a myth. Others felt that while communicative ability is perhaps an issue, TBLT actually addresses this directly, focused as it is on developing this very skill.

Hannah: TBLT addresses the lack of communicative ability, so you solve that problem as you go along. The only students I believe TBLT is unsuitable for are beginners who do not have the vocabulary to draw on in the first place. In those cases, the "weak" form of TBLT can be used, i.e., introducing a particular language point and then using tasks to practice it.

Will: ...the answer is to tailor the activity to students' level and have scaffolding support. Students need to feel successful in the task.

Finally, Fumiya raised the important point that the L1 has a role to play in TBLT classes anyway. This relates back to another common 'misunderstanding' of TBLT, that it does not allow room for the L1 in language classes, which has been disputed by some writers (Cook, 2001; Shimizu, 2006)

Fumiya: You could allow the use of L1 by limiting the situations. I suppose the most important part of TBLT is making classes student-centered, so I do not limit the use of L1, but students learn a lot by their active participation because they have to seek the answers on their own rather than sitting without thinking anything and taking notes on what teachers say.

\section{CONCLUSION}

It is important to remember that the last ' $\mathrm{T}$ ' in TBLT stands for teaching. Due to the fact that TBLT research is often carried out in the laboratories of SLA theorists, much of the work written on the matter over the last few decades takes place outside of real language classrooms. In his plenary address at the 3rd TBLT in Asia 
Conference, Marcos Benevides, the author of Widgets, commonly described as one of the first TBLT textbooks for English language learners, proposed that if TBLT is to move forward, it needs to come out of the laboratory and into the classroom (Benevides, 2016). In order to do so, teachers need clear guidance as to what TBLT is, how to carry it out, and what issues may arise when they do. It this latter point that this paper has focused on.

The results from the data provided by the ten teachers in this study help to gain a clearer picture on how TBLT is being implemented in language classrooms across Japan, and highlights some of the key issues involved. These teachers have found that TBLT engages students, allows them to develop their creativity and autonomy, and frees them from constraints of the 'one correct way' of using the L2 in language teaching. At the same time, it helps to shed light on some of the real issues involved with implementing TBLT in Japan. While the previous learning styles of students are not held to be major obstacles, teachers might take them into consideration when introducing TBLT to a class for the first time by providing extra scaffolding or by beginning with a 'weak' form of TBLT. Also of concern is a lack of materials for both students and teachers. Many teachers are making their own materials or adapting existing ones, but this is time consuming. Teacher training programs should make sure that adequate time is given to providing examples of lesson plans and materials.

Writing about the case of China, Lai (2015) says that "essentialist statements about the cultural inappropriateness of TBLT in Asian contexts may not stand and will not help move the field forward" (Lai, 2015 , p. 24). It is clear from these teachers' responses that many agree with this, and that with small adjustments, students in Japan can be very receptive to, and appreciate the benefits of, TBLT for their language development. In Susan's words 'Students in Japan are not different to those I have taught in other countries assuming the classroom and teaching conditions are the same."

\section{REFERENCES}

Anderson, J. (1993). Is a communicative approach practical for teaching English in China? Pros and cons. System 21, 471-480.

Benevides, M. (2016, June). Widgets: A TBLT textbook postmortem. Plenary paper presented at the Third TBLT in Asia Conference, Ryukoku University, Kyoto.

Borg, S. (2006). Teacher cognition and teacher education: Research and practice. London: Continuum.

Bruton, A. (2005). Task-based language learning: For the state secondary FL classroom? Language Learning Journal, 31, 55-68.

Burrows, C. (2008). Socio-cultural barriers facing TBL in Japan. The Language Teacher, 32(8), 15-19.

Carless, D. (2004). Issues in teachers' reinterpretation of a task-based innovation in primary schools. TESOL Quarterly, 38(4), 639-662.

Carless, D. (2007). The suitability of task-based approaches for secondary schools: Perspectives from Hong Kong. System, 35, 595-608.

Chen, E.S. (2014, October 4). As easy as ABC? English education in Japan. The Diplomat. Retrieved from: https://thediplomat.com/2014/10/as-easy-as-abcenglish-education-in-japan/

Cheng, X., \& Moses, S. (2011). Perceptions and implementation of task-based teaching among secondary school EFL teachers in China.

International Journal of Business and Social Science 2(24), 292-302.

Clark, G. (2009, February 5). What's wrong with the way English is taught in Japan? Japan Times. Retrieved from: https://www.japantimes.co.jp/opinion/2009/02/05/c ommentary/whats-wrong-with-the-way-english-istaught-in-japan/\#.WhIZdbZ7GRs

Cook, V. (2001). Using the first language in the classroom. The Canadian Modern Language Review, 57(3), 402-423.

De Ridder, I., Vangehuchten, L., \& Gomez, S. G. (2007). Enhancing automaticity through task-based language learning. Applied Linguistics 28(2), 309315 .

Ellis, R. (2003). Task-based language learning and teaching. Oxford: Oxford University Press.

Ellis, R. (2009). Task-based language teaching: Sorting out the misunderstandings. International Journal of Applied Linguistics, 19(3), 221-246.

Ellis, R. (2017). Position paper: Moving task-based language teaching forward. Language Teaching, 50(4), 507-526.

Gillham, B. (2005). Research Interviewing: The Range of Techniques (1st ed.). Berkshire: Open University Press.

Harris, J. (2016). Teachers' beliefs about task-based language teaching in Japan. The Journal of Asia TEFL, 13(2), 102-116.

Hu, G. W. (2005). Contextual influences on instructional practices: A Chinese case for an ecological approach to ELT. TESOL Quarterly, 39, 635-660.

Hu, R. (2013). Task-based language teaching: Responses from Chinese teachers of English. TESLEJ, The Electronic Journal for English as a Foreign Language 16(4), 1-21.

Jeon, I. J. (2006). EFL teachers' perceptions of taskbased language teaching: With a focus on Korean secondary classroom practice. Asian EFL Journal 8, 192-206.

Kozawa, Y. (2011). "Facilitating collaborative dialogues through TBLT". In A. Stewart (Ed.), JALT2010 Conference Proceedings, (pp. 217-229). Tokyo: JALT.

Lai, C. (2015). Task-based language teaching in the Asian context: Where are we now and where are we going? In M. Thomas and H. Reinders (Eds.), 
Contemporary task-based language teaching in Asia (pp. 12-29). London: Bloomsbury.

Li, D. (1998). It's always more difficult than you planned: Teachers' perceived difficulties in implementing the communicative approach in South Korea. TESOL Quarterly 32(4), 677-703.

Littlewood, W. (2007) 'Communicative and task-based language teaching in East Asian classrooms'. Language Teaching 40, 243-249.

Long, M. (2015). Second language acquisition and taskbased language teaching. West Sussex, UK: Wiley Blackwell.

Long, M. (2016). In defense of tasks and TBLT: Nonissues and real issues. Annual Review of Applied Linguistics 36, 5-33.

Lowe, R. (2012). Promoting L2 use as a means of facilitating TBLT in Japanese classrooms. The Language Teacher 36(6), 21-26.

Luo, S., \& Xing, J. (2015). Teachers' perceived difficulty in implementing TBLT in China. In M. Thomas and H. Reinders (Eds.), Contemporary task-based language teaching in Asia (pp. 139155). London: Bloomsbury.

McVeigh, B.J. (2001). Higher education, apathy, and post-meritocracy. The Language Teacher 25(10), 29-32.

Mackey, A. (1999). Input, interaction and second language development: an empirical study of question formation in ESL. Studies in Second Language Acquisition, 21(4), 557-589.

MEXT. (2014). English Education Reform Plan corresponding to globalization. Retrieved from http://www.mext.go.jp/en/news/topics/detail/13726 56.htm

Miller, K. K. (2014, October 7). What's wrong with English education in Japan? Pull up a chair. Japan Today. Retrieved from: https://japantoday.com/category/features/lifestyle/w hats-wrong-with-english-education-in-japan-pullup-a-chair

Nakane, I., \& Ellwood, C. (2009). Speech and silence in the clasroom: Japanese students' desire and struggle to speak. In H. Chen \& K. Cruickshank (Eds.), Making a Difference: Challenges for Applied Linguistics (pp. 95-108). Newcastle upon Tyne, UK: Cambridge Scholars Publishing.

Newton, J. (2001). Options for vocabulary learning through communication tasks. ELT Journal, 55(1), 30-37.

Nunan, D. (2004). Task-based language teaching. Cambridge: Cambridge University Press.

Sato, R. (2009). Suggestion for creating approaches suitable to the Japanese EFL environment. The Language Teacher, 33(9), 11-14.

Sato, R. (2010). Reconsidering the effectiveness and suitability of PPP and TBLT in the Japanese classroom, JALT Journal 32(2), 189-200.

Seedhouse, P. (1999). Task-based interaction. ELT Journal 53(3), 149-156.
Sheen, R. (2003). Focus-on-form: A myth in the making. ELT Journal 57(3), 225-233.

Shimizu, M. (2006). Monolingual or bilingual policy in the classroom: Pedagogical implications of L1 use in the Japanese EFL classroom. Kyouaigakuen Maebashi Kokusaidaigaku Ronshuи 6, 75-89.

Shintani, N. (2011). Task-based language teaching versus traditional production-based instruction: Do they result in different processes? University of Sydney Papers in TESOL, 6, 97-120.

Shintani, N. (2016). Input-based tasks in foreign language instruction for young learners. Amsterdam, the Netherlands: John Benjamins.

Skehan, P. (1998). A cognitive approach to language learning. Oxford: Oxford University Press.

Swan, M. (2005). Legislation by hypothesis: The case of task-based instruction. Applied Linguistics, 26(3), 376-401.

Takimoto, M. (2007). The Effects of Input-Based Tasks on the Development of Learners' Pragmatic Proficiency. Applied Linguistics, 30(1), 1-25.

Third-graders can get head start on English classes from fiscal 2018. (2017, May 26). Japan Times.

Retrieved from:

https://www.japantimes.co.jp/news/2017/05/26/nati onal/third-graders-can-get-head-start-englishclasses-fiscal-2018/\#

Van den Branden, K. (2006). Introduction: Task-based language teaching in a nutsehll. In K. Van den Branden (Ed.), Task-based language education: From theory to practice (pp. 1-16). New York: Cambridge University Press.

Viet, N.G., Cahn, L. V., \& Barnard, R. (2015). Two case studies of task-based language teaching in Vietnam. In M. Thomas and H. Reinders (Eds.), Contemporary task-based language teaching in Asia (pp. 68-86). London: Bloomsbury.

Viet, N. G. (2014). Forms or meaning? Teachers' beliefs and practices regarding task-based language teaching: A Vietnamese case study. The Journal of Asia TEFL 11(1), 1-36.

Wakabayashi, S. (2015). What is lacking in English language education in Japan? The Japan News. Retrieved from: http://www.yomiuri.co.jp/adv/chuo/dy/opinion/201 50817.html

Wicking, P. (2009). TBLT in Japan: Task-based language teaching and its effective implementation in the Japanese university classroom. OnCUE Journal, 3(3), 248-258.

Widodo, H. P. (2015). Designing and implementing task-based vocational English materials: Text, Language task, and context in Indonesia. In M. Thomas and H. Reinders (Eds.), Contemporary task-based language teaching in Asia (pp. 291312). London: Bloomsbury.

Willis, D., \& Willis, J. (2007). Doing task-based teaching. Oxford: Oxford University Press.

Willis, D. \& Willis, J. (2009). Why do we need TBLT? The Language Teacher, 33(3), 3-8. 
Willis, D. \& Willis, J. (2011). Task-based learning and learner motivation. OnTask, 1(1), 4-10.

Zhang, Y. (2015). Task-based language teaching in the primary schools of South China. In M. Thomas and H. Reinders (Eds.), Contemporary task-based language teaching in Asia (pp. 87-102). London: Bloomsbury.
Zheng, H. (2015). Teacher Beliefs as a complex system: English Language Teachers in China. Switzerland: Springer

Zheng, H., \& Borg, S. (2014). Task-based learning and teaching in China: Secondary school teachers' beliefs and practices. Language Teaching Research 18(2), 205-221. 